IRA-International Journal of Education \&

Multidisciplinary Studies

ISSN 2455-2526; Vol.09, Issue 02 (November, 2017)

Pg. no. 20-24

Institute of Research Advances

http://research-advances.org/index.php/IJEMS

\title{
Influence of Participation in Athletics on Students' Academic Performance in Uasin Gishu County
}

Charles Nyabero

University of Eldoret, Kenya.

Type of Review: Peer Reviewed.

DOI: http://dx.doi.org/10.21013/jems.v9.n2.p1

How to cite this paper:

Nyabero, C. (2017). Influence of Participation in Athletics on Students' Academic Performance in Uasin Gishu County. IRA International Journal of Education and Multidisciplinary Studies (ISSN 2455-2526), 9(2), 20-24. doi: http://dx.doi.org/10.21013/jems.v9.n2.p1

(C) Institute of Research Advances.

\section{(cc) EY-NC}

This work is licensed under a Creative Commons Attribution-Non Commercial 4.0 International License subject to proper citation to the publication source of the work.

Disclaimer: The scholarly papers as reviewed and published by the Institute of Research Advances (IRA) are the views and opinions of their respective authors and are not the views or opinions of the IRA. The IRA disclaims of any harm or loss caused due to the published content to any party.

Institute of Research Advances is an institutional publisher member of Publishers Inter Linking Association Inc. (PILA-CrossRef), USA. The institute is an institutional signatory to the Budapest Open Access Initiative, Hungary advocating the open access of scientific and scholarly knowledge. The Institute is a registered content provider under Open Access Initiative Protocol for Metadata Harvesting (OAI-PMH).

The journal is indexed \& included in WorldCat Discovery Service (USA), CrossRef Metadata Search (USA), WorldCat (USA), OCLC (USA), Open J-Gate (India), EZB (Germany) Scilit (Switzerland), Airiti (China), Bielefeld Academic Search Engine (BASE) of Bielefeld University, Germany, PKP Index of Simon Fraser University, Canada. 


\begin{abstract}
The study investigated the influence of learners' participation in athletic activitieson academic performance of students in secondary school Uasin Gishu County. The study was grounded on Astin's theory of involvement, whichasserts that students learn more when they are involved in both academic and social aspects of the collegiate experience. The study employed both quantitative and qualitative research process with a target population being students and teachers of Uasin Gishu County. Sample of 378 was calculated with aid Krecie \& Morgan sample table and sample was arrived at through stratified sampling on secondary schools and simple random sampling on selected secondary schools whose students were picked without bias. Tools for data collection included questionnaire, in-depth interview and review of literature. The tools were calibrated on validity and reliability through expert check and Chronbach's Alpha Coefficient, which was 0.76, which was fair enough for utility of the questionnaires.The achieved data was analyzed based on confidence level of 95\%and person correlation coefficient and using descriptive statisticsthat included frequencies, standard deviation and mean. The analysis was carried out with help of SPSS program. The finding indicated that participation in athletic activities has potential to positively influence students' academic performance $(R=0.632$; $p<0.05)$. Athletics participationstimulates fine and gross motor growth, learner concentration and cognitive development. The finding suggests that schools need to create a conducive environment for participation in athletics and encourage the students to participate in order to enhance their performance.
\end{abstract}

Key words: Athletics, learners, academic performance, schools

\title{
Background Information
}

Non-academic activities were viewed as recreational and detrimental to academic achievement and were highly discouraged by stakeholders in education (Marsh \& Kleitman, 2002). In the recent past educational stakeholders have taken a more positive perspective arguing that co-curricular activities including athletics have positive effects in life skills and its benefit being felt in academic accomplishment (Marsh \& Kleitman, 2002; Broh, 2002; Guest \& Schneider, 2003). Co-curricular activities are categorized as informal and formal activities. Athletics falls in the category of formal activities because of its nature of organized structure of operation and practice (Guest \& Schneider, 2003).

Education is a key element in development process, as it enhances skills, knowledge and motivation needed for social economic development (Mahar, 2011). Curriculum normally goes to an extent of teaching and educating students about academic theories. Co-curricular activities have an equal footing in student life especially in the improvement of student ability to grasp things as a whole, because students will have received a more rounded education. Athletics as a co-curricular activity provide opportunity for students to work in teams, to exercise leadership, and to take the initiative themselves about life (Chambers \& Schreiber, 2004).

Many studies have concentrated on relationship between co-curricular activities and academic performance with no much on influence of athletics on the academic performance, which the research sought to establish.

\section{Theoretical Framework}

The study was modeled on Astin's theory who holds that involvement refers to the investment of physical and psychological energy in various objects, this occurs along a continuum. Astin's theory is based on five assumptions on involvement by learners as investment of physical and psychological energy in various objects, occurring along a continuum, it has both quantitative and qualitative features, the amount of student learning and personal development associated with any education program is directly proportional to the quality and quantity of student involvement in that program itself (Astin, 1984). Astin's theory presented a paradigm for viewing student participation in co-curriculum activities, stressing the concept of commitment and time. When compared, capable students tend to be more participative in co-curricular activities than less capable ones (Hunt, 2005).

\section{Research Methodology}

The study was conducted in Uasin Gishu County, which lies in the Rift valley region of Kenya and borders Tranzoia to the North, Elgeyo Marakwet East Kakamega to the west and Nandi to the South East. Both quantitative and qualitative methods were usedin the research process with a target population of 11380 being students all from the Uasin Gishu County. The sample size was derived based on Krecie \& Morgan Sample table, which culminated to 378 expected respondents. This included 335 students and 43 teachers. Questionnaire 
was the main tool for soliciting for data, which accompanied by in-depth interview that could seek clarification of information achieved. Validity of the questionnaire was calibrated with expert opinion from the supervisors while reliability was calculated through Chronabach's alpha coefficient which was 0.76 an indication that the tool could proceed being used in collection of data. A confidence level of $95 \%$ with a margin of error of 0.05 was the basis of the research while carrying out inferential treatment using person correlation coefficient.

\section{Findings of the Study}

\section{Response Rate}

A total of 357 respondents returned dully-filled questionnaire, which could translate, to $94.4 \%$. This was an indication that there was positive reception towards the study.

\section{Demographic characteristics}

Results presented in Table lindicated most of the student respondents (63.3\%) were male. This is consistent with the many schools found in the Countrywith ageranging between 15 years to 17 years $(68.8 \%)$. Most of the respondents were Form $3(44.7 \%)$ and form 2 (28.7\%) with Form 4 students representing paltry $19.8 \%$ andform 1 students were a mere $6.8 \%$.

\section{Table 1: Background Characteristics}

\begin{tabular}{|c|c|c|c|}
\hline Background characteristics & & $\mathbf{N}$ & $\%$ \\
\hline \multirow[t]{3}{*}{ Gender of respondents } & Male & 226 & 63.3 \\
\hline & Female & 131 & 36.7 \\
\hline & Total & 357 & 100.0 \\
\hline \multirow[t]{4}{*}{ Age of respondents } & $12-14$ & 12 & 3.4 \\
\hline & $15-17$ & 246 & 68.8 \\
\hline & $18-20$ & 99 & 27.8 \\
\hline & Total & 357 & 100.0 \\
\hline \multirow[t]{5}{*}{ Class of respondents } & Form 1 & 24 & 6.8 \\
\hline & Form 2 & 102 & 28.7 \\
\hline & Form 3 & 160 & 44.7 \\
\hline & Form 4 & 71 & 19.8 \\
\hline & Total & 357 & 100.0 \\
\hline \multirow[t]{3}{*}{ Participation in co-curricular activities } & Yes & 306 & 85.7 \\
\hline & No & 51 & 14.3 \\
\hline & Total & 357 & 100.0 \\
\hline
\end{tabular}

Furthermore, Results showed that majority of teachers who respondent had first degree (61.5\%), followed by diploma certificate holders (23.1\%) and masters' degree holders (15.4\%). Gender distribution revealed that male teachers were the majority $(69.2 \%)$ while female teachers were $(30.8 \%)$. This is important since presence of female co-curricular teachers is a motivation for girls to be proactive in participating in co-curricular activities. The study findings are presented in Table 2 below.

\section{Table 2: Co-curricular Teachers' Background Information}

\begin{tabular}{|c|c|c|c|}
\hline Background Characteristic & Category & $\mathbf{N}$ & $\%$ \\
\hline \multirow[t]{4}{*}{ Academic Qualification } & Bachelors degree & 26 & 61.5 \\
\hline & Diploma & 10 & 23.1 \\
\hline & Masters & 7 & 15.4 \\
\hline & Total & 43 & 100.0 \\
\hline \multirow[t]{3}{*}{ Gender of Teacher } & Female & 13 & 30.8 \\
\hline & Male & 30 & 69.2 \\
\hline & Total & 43 & 100.0 \\
\hline
\end{tabular}

\section{Students Participation in Athletics Activities}

Athletics is a key co-curricular activityundertaken by students in secondary schools. Means and standard deviations were used to explore students' participation in athletics in the county. Responses were elicited on a 5point scale with discrete measurement values. This scale was however converted to a continuous scale to 
measure average response scores such that $0.5<\mathrm{R}<1.5$ was the threshold for strong agreement; $1.5<\mathrm{R}<2.5$ for agreement; $2.5<\mathrm{R}<3.5$ for moderate agreement; $3.5<\mathrm{R}<4.5$ for disagreement, and $4.5<\mathrm{R}<5.5$ for strong agreement. In this case, ' $\mathrm{R}$ ' was used to denote response.

Results presented in Table 4 show the mean response scores and corresponding standard deviations across key athletics items. The mean response scores tended to indicate appreciation for athletics among the student respondents. In addition, the small values in standard deviations show consistencies in response scores among the students.

Specific results reveal that respondents tended to agree to the following: that they are active members of the school cross-country team $(\mathrm{M}=1.81, \mathrm{SD}=0.501)$; that they spent most of their free time practicing running in the field $(\mathrm{M}=2.02, \mathrm{SD}=0.649)$; that they create time away from their athletics sessions to complete their home work $(\mathrm{M}=2.08, \mathrm{SD}=0.599)$; that they are inspired by previous students of the schools who have made it in athletics $(\mathrm{M}=2.12, \mathrm{SD}=0.595)$; that classmates often marvel at their individual skills $(\mathrm{M}=2.16, \mathrm{SD}=0.616)$; and that athletics is the order of their daily schedules $(\mathrm{M}=2.20, \mathrm{SD}=0.784)$.

They however, tended to moderately agree to the following: that they represent their schools up to county and national levels $(\mathrm{M}=2.87, \mathrm{SD}=0.925)$, that they keenly participate in field events up to the national level $(\mathrm{M}=2.90, \mathrm{SD}=0.829)$; that they compete in track events up to the national level $(\mathrm{M}=2.94, \mathrm{SD}=0.774)$; and that they are hardly in school due to their athletic participation $(\mathrm{M}=3.18, \mathrm{SD}=0.916)$.

\section{Table 4: Participation in Athletics Activities}

\begin{tabular}{lrr}
\hline \hline Items & M & SD \\
\hline I am an active member of the school cross-country team & 1.81 & .501 \\
I spent most of my free time practicing running in the field & 2.02 & .649 \\
I create time away from my athletics sessions to complete my homework & 2.08 & .599 \\
The numbers of past students of this school who have made it in athletics inspire & 2.12 & .595 \\
me. & & .616 \\
My classmates marvel at my skills. & 2.16 & .784 \\
Athletics is the order of my day schedules. & 2.20 & .97 \\
I represent my school up to county and at national level competitions. & 2.90 & .825 \\
I keenly participate in field events up to national level. & 2.94 & .774 \\
I compete in track events up to the national. & 3.18 & .916 \\
I am hardly in school due to my athletics participation. & & \\
\hline \hline
\end{tabular}

It may be concluded from the results that students who participate in athletics activities, they are surely not coerced and fully enjoy the activities. This is particularly so since in the Rift Valley where the county is located, athletics is a way of livelihood to most of the families. Renowned athletes who were former students of the schools in the study area provide the impetus that drives students in their athletics pursuit. It is also worth to note that despite their devotion to the athletics activities, these students find time to complete their homework. The bottom line is that even though they participate in athletics, they recognize their cardinal responsibility as students.

\section{The influence of Students' participation in Athletics on Academic performance}

The study sought to determine how students' participation in athletics influences their academic performance in public secondary schools in Uasin Gishu County. Correlations were used to first establish whether there existed linear relationships between participation in co-curricular activities and academic performance.

Results presented in Table 5 shows that there was a positive and significant correlation between participation in athletics and academic performance $(\mathrm{r}=0.632, \mathrm{p}<0.01)$.

Table 5: Correlation Coefficients

\begin{tabular}{|c|c|c|c|c|c|}
\hline & & 1 & 2 & 3 & 4 \\
\hline 1. Participation in athletics & $\begin{array}{l}\text { Pearson Correlation } \\
\text { Sig. (2-tailed) }\end{array}$ & 1 & & & \\
\hline 2. Academic performance & Pearson Correlation & $.632^{* * *}$ & $.519^{* * *}$ & $.508^{* * *}$ & 1 \\
\hline & Sig. (2-tailed) & .000 & .000 & .000 & \\
\hline
\end{tabular}

**. Correlation is significant at the 0.01 level (2-tailed).

The implication is that participation in athletics has potential to influence academic performance in a non-causal way. $(\mathrm{P}<0.01)$.Consequently, participation in athletics has potential to increase academic performance. 


\section{Conclusion and Recommendation}

In view of the findings from the study it was established that participation in athletics is learner driven with most of them hoping to emulate former students in public secondary schools in the County and who have gone on to excel nationally and internationally. Participation in athletics does not in any way interfere with academic performance of students involved and has potential to lead to improved academic performance by stimulating fine and gross motor growth, learner concentration, and cognitive development among others. It is therefore prudent that schools encourage learners to participate in athletics by providing good atmosphere and infrastructure for the activities to happen smoothly.

\section{References}

[1] Astin, A. (1984). Student involvement: A development theory for higher education. Journey of College Student Personnel, 25 (4), 297-308

[2] Broh, B.A (2002, January). Linking extracurricular programming to academic achievement.

[3] Chambers, E.A, \& Schreiber,J.B. (2004). Girls' academic achievement: varying association of extracurricular activities. Gender and Education, 16 (3), 327-346.

[4] Guest, A., Schneider, B. (2003). Adolescents' extracurricular participation in context; Themediating effects of schools, communities, and identity. Sociology of education, 76, 89-105.

[5] Hunt, D.H. (2005). The effects extracurricular activities in educational process: Influence on academic outcomes. Sociological Spectrum, 2, 417- 445.

[6] Mahar, M.T. (2011). Impact of short bouts of physical activity on attention-to-task in elementary school children. Preventive Medicine, 52(11), 60-64

[7] Marsh, H.W.,\& Kleitman, S.(2002). Extracurricular activities: The good, the bad, and the nonlinear. Harvard Education Review. 